21 (1), 2020,01-11
Jurnal Pendidikan MIPA
e-ISSN: 2685-5488|p-ISSN: 1411-2531
http://jurnal.fkip.unila.ac.id/index.php/jpmipa

\title{
Biology YouTube Videos with Focus Questions: Effects on Student Concept Understanding and Media-literacy Skills
}

\author{
Ariel Tacluyan Capati \\ Department of Biology Education, Institute of Education, Far Eastern University, Philippines
}

\begin{abstract}
This research determined the effects of Biology YouTube videos with focus questions on the concept understanding and media-literacy skills of students aged fifteen in the topic areas of Human Digestion, Heredity, Biodiversity and Interactions. A quasi-experimental research design using pretest-posttest was utilized. Students were divided into two randomly selected groups: experimental and control. Results revealed that Biology YouTube videos with focus questions ( $M=10.68 \pm 2.93$ ) were as good as conventional teaching in enhancing student conceptual understanding $(\mathrm{M}=10.69 \pm 2.94)$ of Biology topics $(\mathrm{p}=.496)$. The study also showed that the strategy also developed media-literacy skills of the students $(p=.000)$. Furthermore, it was found that conceptual understanding positively and significantly influenced media-literacy skills of students $(\mathrm{r}=.459 ; \mathrm{p}=.003)$ and vice-versa $(\mathrm{r}=.459 ; \mathrm{p}=.003)$. It is recommended that the strategy introduced in this study be used in facilitating media literacy in other allied science subjects, in other subjects, and in the teaching of media-literacy education to educators and students of different year levels.
\end{abstract}

Keywords: biology youtube videos with focus questions, concept understanding, media-literacy skills.

Abstrak: Penelitian ini menentukan efek dari video YouTube materi Biologi dengan pertanyaan-pertanyaan fokus pada pemahaman konsep dan keterampilan media-literasi siswa berusia lima belas tahun, pada topik Pencernaan Manusia, Keturunan, Keanekaragaman Hayati dan Interaksi. Desain penelitian eksperimen semu dengan pretest-posttest digunakan, dimana siswa dibagi menjadi dua kelompok yang dipilih secara acak: eksperimental dan kontrol. Hasil penelitian mengungkapkan bahwa video YouTube Biologi dengan pertanyaan fokus $(M=10,68 \pm 2,93)$ sama baiknya dengan pengajaran konvensional $(M=10,69 \pm 2,94)$ dalam meningkatkan pemahaman konseptual siswa $(p=0,496)$. Penelitian ini juga menunjukkan bahwa strategi ini juga mampu mengembangkan keterampilan media-literasi siswa $(p=.000)$. Selanjutnya, ditemukan bahwa pemahaman konseptual secara positif dan signifikan mempengaruhi keterampilan media-literasi siswa $(r=, 459 ; p=, 003)$ begitu juga sebaliknya $(r=, 459 ; p=, 003)$. Direkomendasikan bahwa strategi yang diperkenalkan dalam penelitian ini digunakan dalam memfasilitasi literasi media dalam mata pelajaran sains lainnya yang serumpun, lebih luas dalam mata pelajaran lain, dan dalam pengajaran pendidikan literasi media kepada para pendidik dan siswa dari berbagai tingkat tahun pendidikan.

Kata kunci: video youtube biologi dengan pertanyaan fokus, pemahaman konsep, keterampilan literasi media.

Ariel Tacluyan Capati

Email: acapati@feu.edu.ph
DOI: http://dx.doi.org/10.23960/jpmipa/v21i1.pp01-11

Received: 13 December 2019

Accepted: 16 January 2020 


\section{- INTRODUCTION}

To upgrade the standard of education in the Philippines, the country's political and education leaders pushed forward the implementation of the $\mathrm{K}$ to 12 Curriculum. This program emphasizes the development of scientific literacy and recognizes the crucial role of technology in daily life. The K-12 Science Curriculum Guide (2013) of the Department of Education highlighted the significant role of science and technology in dealing with everyday human affairs related to civic, personal, social, economic, values, and ethics. Also, the agency accentuated the connection and integration of science and technology to Filipino culture and identity in curriculum and instruction. Integration can be done horizontally,where science and technology's purposes are seen by understanding and solving real-life problems together with other subjectsor vertically, where difficulty and complexity are observed as students move from one grade level to the next.

One of the subjects integrated in the Grade 8 science curriculum is Biology. Biology, as generally perceived by the students, is a subject to be memorized (Cimer, 2004). Because of this, students tend to employ low-level thinking skills and learn only facts (Ursavas, 2012). Studies have shown that students often do not think in multidimensional levels and hold naive understandings (Maskiewicz, 2006; Grotzer \& Basca, 2003; Grotzer \& Perkins, 2000; White, 2000; Driver, 1994). In addition, many researchers in biology education also showed that teacher-centered and memorizationbased strategies are often the cause of student'slow level understandings (Ursavas, 2012; Cimer, 2004; Lin \& Hu, 2003; Okebukola, 1990).

In search of a solution to address these problems, many biology educators have developed teaching strategies such as integrating technology into their lessons and the use of video-sharing websites like YouTube to explain a specific biological concept. However, the use of such visual learning tools does not always support learning and usually leaves the students with superficial understanding of biological terms and processes (Harp \& Mayer, 1998; Levie\& Lentz, 1982; Mayer, 1997; 2005). Often, teachers use a YouTube video as a motivational tool or a means to discuss biological information without any follow-up strategies to assess student concept understanding. This can be counterproductive since students need to understand concepts and their relationships, value, and application to daily life. Furthermore, students may be exposed to uncensored information that might promote racism, sexism, chauvinism, prejudice, dogmatism and the like. Students then need to develop the skills and knowledge to filter media information appropriately and purposefully to support their educative needs. Hence, aside from ensuring that students learn scientific concepts, it is equally imperative to properly select the information coming from various websites to ensure that they promote critical thinking, appropriate values, and media-literacy skills.

Flood, Heath, \& Lapp (1997) emphasized that society now demands the ability to engage in the meaning-making process from increasingly complex and layered combinations of messages that use video, audio, and print representations. In a study made by Inan \& Temur (2012), it was found that family and school form the two pillars of media-literacy consciousness, with emphasis on the pivotal role of teachers. Moreover, media literacy is a vital part of the $\mathrm{K}$ to 12 curriculum that is lacking in most of the strategies employed by teachers as this topic is only offered in Grade 11 curriculum in the Philippines.

Thus, in this study, the researcher utilized biology YouTube videos with focus questions to facilitate the development of conceptual understanding and media-literacy 
skills among Grade 8 biology students. The use of questions in the teaching-learning process in science has been hailed as an effective teaching strategy to engage students and promote a process of sustained reasoning crucial in the development of understanding (Berntson \& Goodman, 2000; National Research Council, 2000; American Association for the Advancement of Science, 1993). Thoughtful questions such as focus questions play an important role in facilitating students' higher-level cognitive processes, such as self-reflection, revision, social negotiation, and conceptual change of student misconceptions (Lustick, 2010; Yang, Newby, \& Bill, 2005). Focus questions, in the context of this research, are combinations of concept understanding and media-literacy skills questions given during or at the end of Biology YouTube video presentation. This teaching strategy bridges the gap on the focus of either concept understanding or media-literacy skills that most researches overlook. Thus, this study is conducted to investigate the effects of using Biology YouTube videos and support focus questions on conceptual understanding and media-literacy skills of Grade 8 biology students. Moreover, it also explores the influence of concept understanding on medialiteracy skills and vice versa. Using the theories from the related literatures, specifically the work of Lustick (2010) and Hobbs \& Frost (2003), this study used focus questions as a support and further stimulus for thinking while viewing YouTube videos in Biology to develop conceptual understanding and media-literacy skills of the students.

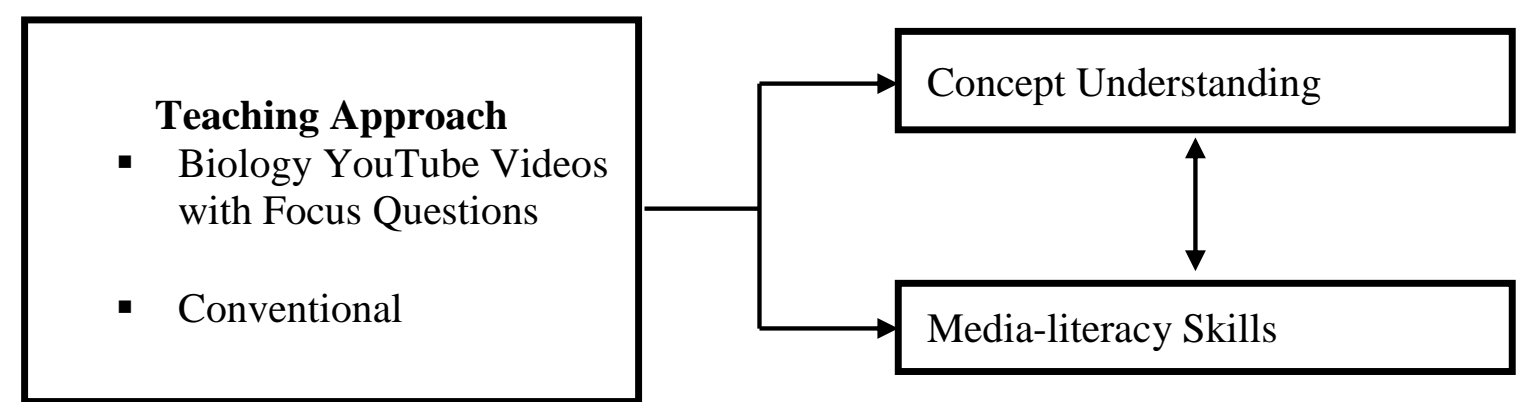

Figure 1. Conceptual framework

The conceptual framework above is a representation of the ideas of this study. Lustick (2010) formed the grounds of utilizing focus question framework for better concept understanding in science. On the other hand, the researches of Hobbs and Frost (2003) entitled "Measuring the acquisition of media-literacy skills" and Inan and Temur's (2012) "Examining Media Literacy Levels of Prospective Teachers" became the foundation in measuring the acquisition of media-literacy skills of students. The biggest rectangular box at the left side of the framework represents the types of teaching approaches. These teaching approaches are used to develop conceptual understanding and media-literacy skills, as represented by the two, smaller, rectangular boxes at the right of the framework. Additionally, the double-headed arrow that connects the concept understanding and media-literacy skills is used to determine whether one factor significantly and positively influence the other and vice versa. 


\section{- METHOD}

\section{Research Design}

This study utilized a quasi-experimental approach with two-group pretest-posttest design. One group was exposed to the strategy (Biology YouTube Videos with Focus Questions Group; $\mathrm{X}_{1}$ ) andthe other was not (Conventional Group; $\mathrm{X}_{2}$ ). Both groups took the pretests $\left(\mathrm{O}_{1}{ }^{\prime}\right)$ and posttests $\left(\mathrm{O}_{2}{ }^{\prime}\right)$ : Concept Understanding Test (CUT); $\mathrm{O}_{1}$ and the Media-literacy Skills Scale (MLSS); $\mathrm{O}_{2}$. The differences in both groups were compared to see if the strategy had an effect on the concept understanding and medialiteracy skills of the students.

\section{Sampling Procedure}

The research participants were all Grade 8 female students in a Catholic institution administered by the Benedictine congregation. Two comparable sections were involved in the study. Both classes were conducted for 55 minutes/meeting, two times a week, for two quarters (June - October 2013).The topics included in the study for these quarters were: Human Digestive System (anatomy, chemical changes in food, diseases from nutrient deficiency and ingestion of harmful substances, prevention, detection and treatment of diseases, contemporary health issues and overall wellness), Heredity (organelles involved in cell division, mitosis, oogenesis and spermatogenesis), Biodiversity (species diversity, hierarchical taxonomic system, protection and conservation of rare and economically important species), and Interactions (energy transformation, biogeochemical cycles, impact of human activities in an ecosystem).

Each group was randomly assigned to either the experimental group or the control group. A teaching strategy that involves lecture-discussion, group reporting, slide presentations, group dynamics, argumentations/debates, article analyses, laboratory activities, model-making activities, were utilized in both groups. The only difference was that the experimental group was exposed to YouTube videos with focus questions.

\section{Research Instruments}

The researcher used two types of research instruments to gather quantitative data in determining the concept understanding and media-literacy skills of the students. The items in the instruments which were adapted by the researcher were extensively tested for their validity and reliability by different experts in the field of educational research. The items in the Concept Understanding Test were revised to eliminate misconceptions. Additionally, the items in the Media-literacy Skills Scale were also modified to fit the cultural and contextual backgrounds of Grade 8 students.

For the teaching intervention, a pilot test was conducted with thirty-eight (38) third year students, three days before the administration of the pretest to the control and experimental groups. Third year students were chosen as participants for this test based on the assumption that they were already familiar with the biology topics being tested, as they had completed them last year. The items in the instruments were modified after the pilot test. Below are descriptions of the instruments used in the research.

\section{a. Concept Understanding Test (CUT)}

The experimental and control groups took a twenty-item CUT pretest and posttest. The pretest was given in June 2013 and the posttest in October 2013, after the topics had been taught. The CUT was designed to gather data about student conceptions. Test items were distributed according to the lessons taken up during the treatment period. 
Each item has four choices. Item questions were constructed by the researcher based on the topics covered in the study. It has a Cronbach's Alpha value of .70 which shows that the items are appropriate to the basic competencies and cognitive levels of Grade 8 students.

\section{b. Media-literacy Skills Scale (MLSS)}

Both groups took a pretest in June 2013 and posttest after the treatment in October 2013. The pretest and posttest were assessed using the survey method. The researcher used the work of Inan \& Temur (2012) as a template. According to the researchers, the power of giving responses to media messages can be considered as one of the powerful tools to assess media literacy. Giving comments or criticisms toward positive or negative messages shows consciousness, critical thinking and active participation of a critical media consumer.

The media-literacy skills scale is divided into two categories - internet/global media network and television media. Each category is made up of a ten-item survey question. Both categories measure the media-literacy skills of Grade 8 students. The Media-literacy Skills Scale (Internet/Global Media) has a reliability coefficient of .79 while that of the Media-literacy Skills Scale (TV Media) has a value of .78. These values, which are consistent for the two categories of the instrument, indicate that they fit the cultural and contextual backgrounds of Grade 8 students. Also, these signify the clarity of the survey questions used in the study.

\section{- RESULT AND DISCUSSION}

\section{Concept Understanding in Biology Education}

The initial comparison of the control and experimental groups' concept understanding in the Grade 8 biology topics covered during the semester was made through the pretest. Based on the results, the pretest mean score of the control group is slightly higher $(M=9.42)$ than the pretest mean score of the experimental group $(M=$ 8.88). However, two-tailed $t$-test revealed that the two groups were not significantly different $(\mathrm{p}=.273)$. Therefore, they can be considered as equivalent groups before conducting the research.The statistical results of the pretest and posttest mean scores of the two groups are presented in Table I.

Table I. T-test of pretest and posttest mean scores in the concept understanding test

\begin{tabular}{lllllll}
\hline Group & Test & Mean & SD & $\begin{array}{l}\text { Std. } \\
\text { error } \\
\text { mean }\end{array}$ & df & $\begin{array}{l}\text { Sig. } \\
\text { (one- } \\
\text { tailed) }\end{array}$ \\
\hline Control & Pretest & 9.42 & 1.97 & .31 & 40 & .018 \\
\multirow{2}{*}{ Experimental } & Posttest & 10.69 & 2.89 & .45 & & \\
& Pretest & 8.88 & 2.53 & .39 & 40 & .000 \\
& Posttest & 10.68 & 3.43 & .54 & & \\
\hline
\end{tabular}

The pretest-posttest mean scores of both groups are statistically significant. The results show that both groups improved in concept understanding as they were exposed to various biological topics for two quarters using two different teaching approaches. The knowledge gained by the students as a set of conceptual tools was beneficial as they applied it to their daily lessons and activities (Toledo, 2010). 
For the posttest mean scores of the two groups, data revealed that that there is no significant difference $(\mathrm{p}=.496)$ between the use of YouTube videos with focus questions in the experimental group $(M=10.69)$ and the strategies employed in the control group $(\mathrm{M}=10.68)$. The factors that may contribute to this result are the following: (a) Both groups are almost similar with regard to their achievement test score in science. According to the profile summary of the test score in science (this subtest measures the student's ability to understand basic concepts of physical and biological sciences and to use inquiry skills related to the aspects of the environment) given by the guidance counselor and guidance coordinators, the control group had 7.8 grade equivalents and the experimental group had 8.1 which are very similar; and (b) Both groups have the same learning styles. Again, based on the profile summary of Grade 8 students, the control and experimental groups have the same top three learning styles. The arrangement of the types of learning in decreasing order is as follows: Digital Learning (includes fluency in new media, online communities, guided mentoring, video games, or collective reflection via blogs, podcasts, wiki's, flicker, twitter, and other forms of social media); Auditory learning (Includes learning more through listening to lectures, music, reciting, and talking to people. Also, it was revealed in the test that written information may have little meaning to them until it is heard); and Visual learning (includes the use of visualization for memory and decision making - often getting insights about something. Additionally, students like to be shown concepts, ideas or how something is done).

\section{Media-literacy Skills}

a. Media-literacy Skills - Internet/Global Media Network

The preliminary comparison of the control and experimental groups' medialiteracy skills covered during the semester, which are categorized into Internet/Global Network Media and TV Media, in the Grade 8 biology topics, was made through the pretest. Based on the results, the pretest mean score of the control group's internet/global media-literacy skills $(\mathrm{M}=27.73)$ is higher than that of the experimental group $(\mathrm{M}=27.71)$ by 1.98 . With the $\mathrm{p}$-value of 0.51 , it can be said that, there is no significant difference with regard to their internet/global media-literacy skills. Therefore, the two groups are statistically equivalent before the start of the research. Table II shows the pretest-posttest mean scores of the control and experimental groups in the Internet/Global Media Network Media-literacy skills.

It was clearly shown that there was no significant difference between the control group's media-literacy skills before and after the study $(\mathrm{p}=.333)$. On the other hand, the difference in the mean scores of the experimental group is statistically significant ( $\mathrm{p}$ $=.000$ ). This result is supported by the study of Lustick, Hobbs, \& Frost (2010) that quality focus questions stimulate curiosity, maintain interest, and connects student's life experiences to be able to analyze, criticize and evaluate media information. The posttest mean scores of the control $(M=27.37)$ and experimental $(M=41.00)$ experimental groups supported the aforementioned deduction. With the p-value of .000 , it is noted that there is a significant difference in the Internet/Global Media Network medialiteracy skills of the two groups in favor of the experimental group. The experimental group's high Internet/Global Media Network media-literacy skills can be attributed to the use of Biology YouTube videos with focus questions. The use of questions in teaching has been hailed as one of the vital tools in the learning acquisition of the students. The questions referred to above were constructed in a way that they gave the 
students the chance to analyze, evaluate, and communicate the information embedded in each video through the following media-literacy dimensions - Identify, Intention, Standpoint, Strategy, and Judgment.

Table II. T-test of pretest and posttest mean scores in the Media-literacy Skills Scale Internet/Global Media Network

\begin{tabular}{|c|c|c|c|c|c|c|}
\hline Group & Test & Mean & SD & $\begin{array}{l}\text { Std. } \\
\text { error } \\
\text { mean }\end{array}$ & Df & $\begin{array}{l}\text { Sig. } \\
\text { (one- } \\
\text { tailed) }\end{array}$ \\
\hline Control & $\begin{array}{l}\text { Pretest } \\
\text { Posttest }\end{array}$ & $\begin{array}{l}27.73 \\
27.37\end{array}$ & $\begin{array}{l}4.27 \\
5.42\end{array}$ & $\begin{array}{l}.67 \\
.85\end{array}$ & 40 & .333 \\
\hline Experimental & $\begin{array}{l}\text { Pretest } \\
\text { Posttest }\end{array}$ & $\begin{array}{l}29.71 \\
41.00\end{array}$ & $\begin{array}{l}4.74 \\
7.32\end{array}$ & $\begin{array}{l}.74 \\
1.1\end{array}$ & 40 & .000 \\
\hline
\end{tabular}

The questions were used every time there is utilization of YouTube video in classroom instruction. After the students have answered the focus questions for medialiteracy skills, the teacher-researcher evaluated their understanding by getting their ideas as well as their opinions regarding the use of video via socialized recitation. In this way, students could filter-out each other's idea, making them participate in the discussion. This was a good sign of learning because students were not passive, instead, they had the chance to reflect on and appraise their media consumption (Eggerton, 2006).

b. Media-literacy Skills - Television Media

Another area that was probed in this study is the TV Media literacy skills of the students. The results show that the two groups are comparable and can be involved in studying the TV media-literacy skills of the students $(\mathrm{p}=.104)$. Nielsen published a statistically important survey that in Mega Manila, the teenagers, on the average, watch 3.4 hours TV per day. The females watch more TV shows than males, with the average 3.9 viewing hours versus 2.5 viewing hours of their male counterparts. This report highlighted the importance of media especially TV since the respondents of this study are all females studying in an exclusive school in the heart of Manila. The comparative results of the pretest-posttest mean scores in the media-literacy skills in Television media are presented below.

Table III. T-test of pretest and posttest mean scores in the Media-literacy Skills Scale Television Media

\begin{tabular}{lllllll}
\hline Group & Test & Mean & SD & $\begin{array}{l}\text { Std. } \\
\text { error } \\
\text { mean }\end{array}$ & Df & $\begin{array}{l}\text { Sig. (one- } \\
\text { tailed) }\end{array}$ \\
\hline Control & Pretest & 29.12 & 5.39 & .82 & 40 & .267 \\
& Posttest & 28.24 & 7.74 & 1.2 & & \\
Experimental & Pretest & 30.93 & 4.50 & .70 & \multirow{2}{*}{40} & .000 \\
& Posttest & 39.00 & 7.10 & 1.1 & & \\
\hline
\end{tabular}

In Table III, it is clear that there is no significant difference in the media-literacy skills in Television media of the control group before $(M=29.12)$ and after $(M=28.24)$ the study $(\mathrm{p}=.267)$. On the other hand, the experimental group has gained advantage 
as regards the repeated use of focus questions in enhancing their media-literacy skills by filtering out a variety of media information $(p=.000)$. The same can be said with the posttest results of both groups. The data suggests that there is a statistically significant difference control $(M=28.24)$ and experimental $(M=39.00)$ groups'TV media-literacy skills $(\mathrm{p}=.000)$. The use of focus questions is undoubtedly helpful in promoting medialiteracy among the students (Lustick, 2010).

\section{Linear Regression of Concept Understanding and Media-literacy Skills}

Table IV presents the linear regression of the concept understanding of control group and experimental group to media-literacy skills. Table IV shows that in both experimental and control groups, concept understanding and media-literacy skills are moderately correlated ( $\mathrm{r}$ values of .459 and .495 , respectively; $\mathrm{p}=.001$ and .003 , respectively) and that concept understanding has significantly influenced media-literacy skills.

Table IV. Linear regression of post concept understanding test to post Media-Literacy Skills Scale in biology

\begin{tabular}{lllllll}
\hline Group & R & \multicolumn{2}{l}{$\begin{array}{l}\text { Unstandardized } \\
\text { Coefficients }\end{array}$} & $\begin{array}{l}\text { Standardized } \\
\text { Coefficients } \\
\text { Beta }\end{array}$ & T & Sig. \\
\cline { 3 - 6 } & & B & $\begin{array}{l}\text { Std. } \\
\text { error }\end{array}$ & & & \\
\hline Control & .495 & 3.72 & 1.03 & .495 & 3.60 & .001 \\
Experimental & .459 & 1.83 & .567 & .459 & 3.23 & .003 \\
\hline
\end{tabular}

The similar results of both groups can be attributed to the gain and application of knowledge of the students for two long quarters. A variety of teaching strategies were given to both groups in four months. These strategies are lecture-discussion, group reporting, slide presentations, group dynamics, argumentations/debates, article analyses, laboratory activities, and model-making activities. The only difference is that the experimental group was exposed to Biology YouTube videos with focus questions.

The gain and application of knowledge is vital in analyzing and evaluating media messages. Sperry (2012) underscored in his study that in a science classroom, students must be taught to carefully examine information and messages in different types of media by applying knowledge and identifying document-based information. Through these techniques, students can draw a well-reasoned conclusion from the given evidences, evaluate different interpretations, reflect on the biases, as well as share the results of their observation to the scientific community. Lastly, Scheibe \& Rogow (2012) emphasized in their research entitled "The Teacher's Guide to Media Literacy," that Science and media-literacy share a very-deep relationship in fostering the process of inquiry.

In Table $\mathrm{V}$, the linear regression of the media-literacy skills of conventional group and experimental group to concept understanding is shown. In a similar manner, the data shown in the previous table indicated that in both the control and experimental groups, there was a significant moderate correlation of media-literacy skills and concept understanding ( $\mathrm{r}$ values of .495 and .459 , respectively) and that media-literacy skills positively influenced concept understanding. 
Table V. Linear regression of post Media-Literacy Skills Scale to post concept understanding test in biology

\begin{tabular}{lllllll}
\hline Group & R & \multicolumn{2}{l}{$\begin{array}{l}\text { Unstandardized } \\
\text { Coefficients }\end{array}$} & $\begin{array}{l}\text { Standardized } \\
\text { Coefficients }\end{array}$ & T & Sig. \\
\cline { 3 - 6 } & & Beta & $\begin{array}{l}\text { Std. } \\
\text { error }\end{array}$ & & & \\
\hline Control & .495 & .066 & .018 & .495 & 3.60 & .001 \\
Experimental & .459 & .115 & .036 & .459 & 3.23 & .003 \\
\hline
\end{tabular}

Marlene Thier (2008) emphasized in her study that students develop a habit of healthy skepticism when they view media messages and information analytically. The National Science Education Standard considers this as indispensable to the nature of science: "Science distinguishes itself from other ways of knowing...through the use of empirical standards, logical arguments, and skepticism" (National Research Council, 1996). Additionally, Thier (2008) argued that a healthy skepticism allows the students to be open to new ideas or information as well as being unconvinced when there is no sound basis of a claim. Thus, media literacy promotes critical and scientific thinking skills.

Media-literacy in the science classrooms means that the students are able to evaluate different media messages associated to science concepts from TV programs, radio programs, newspapers, internet, and others (Thier, 2008). Students are skilled in comparing media forms and presentations of the same topic as well as how to use media information judiciously in various science topics. Likewise, students need to be able to synthesize new information by drawing on various sources and effectively use a variety of media as part of their science learning. In the study made by Sperry (2012), he stressed that the consistent use of a set of questions about all the media messages that address sourcing, meaning, and credibility is imperative in decoding media information in the science classrooms. Thus, the research of Sperry (2012) and Thier (2008) provided strong support for the data analysis and interpretation of Table V.

\section{- CONCLUSION}

The use of Biology YouTube videos with focus questions and conventional teaching equally improve the concept understanding of the students. Students' medialiteracy skills, however, are significantly improved by using Biology YouTube videos with focus questions. Furthermore, student concept understanding is a significant positive predictor of media-literacy skills and vice versa. For further studies, it is recommended: (1) to utilize Biology YouTube videos with focus questions in other biology topics in teaching media-literacy skills. The emergence of different types of media designed to teach Biology in our modern time is crucial not only to aidunderstanding of biological topics but also to consider and make students aware of the embedded media messages that may contain racism, sexism, and prejudice; (2) that the use of Biology YouTube Videos with focus questions be explored in relation to other specialized science subjects such as Earth Science, Ecology, Chemistry, and Physics as well as other subjects (e.g., Social Studies, English, Mathematics,) that utilize various types of media; (3) that the strategies use in this study be tested with students at the primary levels or among male high school students to facilitate media- 
literacy skills since most of them are exposed to various forms of media at the very young age; and (4) that the strategies used in this study be applied by future researchers in classroom instruction using other types of media such as radio, magazine, and billboard advertisements in developing student's media-literacy skills.

\section{- REFERENCES}

American Association for the Advancement of Science. (1993). Benchmarks for science literacy. New York: Oxford University.

Berntson, G. \& Goodman, L.(2000). The art of asking questions. American Biology Teacher, 62, 473-476.

Carr, D. (1998). The art of asking questions in the teaching of science. School Science Review, 79(289), 47-60.

Çimer, A. (2004). A study of Turkish biology teachers' and students' views of effective teaching in schools and teacher education. EdD Thesis, The University of Nottingham School of Education, Nottingham, U.K..

Department of Education. (2013). K to 12 Curriculum Guide Science. Pasig City, Philippines. http://www.deped.gov.ph/k-to-12/bec-cgs/als-program.

Flood, J., Heath, S.B., \& Lapp, D. (1997). Research on teaching literacy through the communicative and visual arts. New York: Macmillan.

Grotzer, T.A., \& Basca, B. B. (2003). Helping students to grasp the underlying causal structures when learning aboutecosystems: How does it impact understanding? Journal of Biological Education, 38(1), 1629.

Grotzer, T.A., \& Perkins, D.N. (2000). The teaching of intelligence: A performance conception. In R. Stemberg (Ed.) Handbook on Intelligence. New York: Cambridge University Press.

Harp, S. F. \& Mayer, R. E. (1998). How seductive details do their damage: A theory of cognitive interest in science learning. Journal of Educational Psychology, 90(3), 44-434.

Hobbs, R. \& Frost, R. (2003). Measuring the acquisition o f media-literacy skills, Reading Research Quarterly. 38(3), 330-355.

Inan, T., \& Temur, T. (2012). Examining Media Literacy Levels of Prospective Teachers. International Electronic Journal of Elementary Education, 269-285.

Levie, W. H., Lentz, R. (1982). Effects of text illustrations: A review of the research. Educational Communications and Technology Journal, 30(4), 195-232.

Lin, H. (2011). Facilitating learning from animated instruction: Effectiveness of questions and Feedback as attention-directing strategies, 14(2), 31-42.

Lustick, D. (2010). The Priority of the Question: Focus Questions for Sustained Reasoning in Science. Journal of Science Teacher Education, 21, 495-511.

Maskiewicz, A. L. (2006), Rethinking Biology Instruction: The Application of DNRbased Instruction to the Learning and Teaching of Biology. Unpublished $\mathrm{PhD}$ Thesis. California: University of California, San Diego.

Mayer, R. E. (2005). Multimedia learning. New York, NY: Cambridge University Press.

Mayer, R. E., Heiser, J., \& Lonn, S. (2001). Cognitive constraints on multimedia learning: When presenting more material results in less understanding. Journal of Educational Psychology, 93(1), 187-198.

National Research Council. (1996). National science education standards. Washington, DC: National Academic Press. 
National Research Council. (2000). Inquiry and the national science education standards: A guide for teaching and learning. Washington, DC: National Academy Press.

Okebukola, P.A. (1990). Attaining meaningful learning of concepts in genetics and biology: An examination of thepotency of concepts of concept mapping techniques. Journal of Research in Science Teaching, 27(5), 493-504.

Scheibe, C., and F. Rogow. (2012). The teacher's guide to media literacy: Critical thinking in a multimedia world. Thousand Oaks, CA: Corwin.

Sperry, C. (2012). Teaching critical thinking through media literacy. National Science Teachers Association, 56-61.

Thier, M. (2008). Media and science: developing skepticism and critical thinking. National Science Teachers Association, 20-24.

Ursavas, N. (2012). Student Teachers' Ways of Thinking and Ways of Understanding Digestion and the Digestive System in Biology. International Education Studies, $1-15$. 